\title{
Study on the Electrical Injection Regeneration of Industrialized B-Doped Czochralski Silicon PERC Solar Cells
}

\author{
Jiaxing Ye $\mathbb{D},{ }^{1,2}$ Bin Ai $\mathbb{D}^{1},{ }^{1}$ Jingsheng Jin, ${ }^{3}$ Depeng Qiu, ${ }^{1}$ Runxiong Liang, ${ }^{1}$ and Hui Shen ${ }^{1}$ \\ ${ }^{1}$ School of Materials Science and Engineering, Guangdong Provincial Key Laboratory of Photovoltaic Technology, \\ Sun Yat-sen University, Guangzhou 510006, China \\ ${ }^{2}$ China National Electric Apparatus Research Institute Co. Ltd., Guangzhou 510300, China \\ ${ }^{3}$ Jinko Solar Holding Co. Ltd., Haining 314416, China
}

Correspondence should be addressed to Bin Ai; stsab@mail.sysu.edu.cn

Received 29 January 2019; Revised 8 April 2019; Accepted 11 April 2019; Published 20 June 2019

Academic Editor: Yanfa Yan

Copyright (c) 2019 Jiaxing Ye et al. This is an open access article distributed under the Creative Commons Attribution License, which permits unrestricted use, distribution, and reproduction in any medium, provided the original work is properly cited.

In this paper, $156 \mathrm{~mm} \times 156 \mathrm{~mm}$ boron-doped Czochralski silicon $(\mathrm{Cz}-\mathrm{Si})$ wafers were fabricated into PERC solar cells by using the industrial standard process; then, the as-prepared PERC solar cells were treated by the regeneration process using electrical injection and heating and the effects of different regeneration processes (temperature, time, and injection current) on the antilight-induced degradation (anti-LID) performance of the PERC solar cells were investigated. The results show that under the condition of $10 \mathrm{~A}$ injection current and $30 \mathrm{~min}$ processing time, the optimal processing temperature is about $180^{\circ} \mathrm{C}$ for $\mathrm{PERC}$ solar cells to obtain the best anti-LID performance. Under the conditions of a temperature of $180^{\circ} \mathrm{C}$, an injection current of $10 \mathrm{~A}$, and a processing time of 0-30 min, the anti-LID performance of the PERC solar cells is enhanced with the increase in the processing time. When the processing time is 20 and $30 \mathrm{~min}$, the efficiency, the short-circuit current, and the open-circuit voltage of the processed PERC solar cells are slightly higher than the initial values before the regeneration and remain stable in the subsequent 12 -hour light degradation process at $45^{\circ} \mathrm{C}$ and 1 -sun illumination. At a temperature of $180^{\circ} \mathrm{C}$ and a processing time of $30 \mathrm{~min}$, the injection current of $6 \mathrm{~A}$ is enough to obtain a good regeneration effect, but the optimal injection current is around $10 \mathrm{~A}$.

\section{Introduction}

Depending on the competitive advantages of low cost, high efficiency, long service life, mature process technology, and so on, boron-doped p-type crystalline silicon solar cells have firmly occupied the dominant position in the globe photovoltaic market all along, but there exists the problem of lightinduced degradation (LID) for such kind of solar cells and this problem has severely hindered their development for a long time. Thus, the investigation on the LID and its mitigation of boron-doped p-type crystalline silicon solar cells has been paid much attention all the time $[1,2]$. In recent years, with the maturation of $\mathrm{Al}_{2} \mathrm{O}_{3}$ back passivation and laser ablation technology, more and more photovoltaic manufacturers are gradually upgrading from producing conventional aluminum back surface field (Al-BSF) solar cells to PERC (passivated emitter and rear cell) solar cells with an efficiency of over $20 \%[3,4]$. As compared with Al-BSF solar cells, the LID of the PERC solar cells is much severer and faster [5]. Therefore, the research on LID and its mitigation of PERC solar cells has attracted great interest and high attention among the photovoltaic community.

It is generally thought that the LID is caused by the formation of the boron-oxygen- (B-O-) related defects with recombination activity in boron-doped p-type crystalline silicon wafers when illuminated [1]. In 2006, Herguth et al. discovered that when boron-doped $\mathrm{Cz}-\mathrm{Si}$ wafers were injected with carriers (illumination or electric injection) 
while heated $\left(60-200^{\circ} \mathrm{C}\right)$, B-O defects would undergo a regeneration reaction; that is to say, $\mathrm{B}-\mathrm{O}$ defects would transform from the degraded state with recombination activity to the regenerated state without recombination activity, and the loss of minority carrier lifetime caused by LID could be fully recovered. More importantly, the regenerated state of the $\mathrm{B}-\mathrm{O}$ defects is stable under the working conditions of solar cells $[6,7]$.

It should be noted that previous researches on $\mathrm{B}-\mathrm{O}$ defect-induced degradation (BO-LID) and its mitigation were almost carried out on lifetime samples (i.e., $\mathrm{Cz}$-Si wafers with sawing damage being removed and the surface being passivated). However, boron-doped $\mathrm{Cz}$-Si solar cells are very different from boron-doped Cz-Si lifetime samples; thus, it is necessary to directly investigate the LID and its mitigation of boron-doped $\mathrm{Cz}-\mathrm{Si}$ solar cells, especially the newly emerging boron-doped Cz-Si PERC solar cells. However, there is a lack of reports on such a subject in the literature. Just as Basnyat et al. from the National Renewable Energy Laboratory (NREL) of the United States described in their paper in 2015, "Although a great deal of information is available on B-O effects in silicon, LID in solar cell has not been understood fully. LID effect on crystalline silicon solar cells is studied by a small number of research groups, using comparatively small sets of samples. Even the results reported in literature show large diversity" [8]. Although Herguth's team at the University of Konstanz and Rein's team at the Fraunhofer Institute for Solar Energy Systems (ISES) first reported their research results on the LID and regeneration of PERC solar cells in 2015 [9-12], their studies were based on the PERC solar cells prepared in laboratory; thus, their research results cannot represent those of industrialized PERC solar cells. Specifically speaking, Herguth's team studied the PERC solar cells with the back surface being passivated by $\mathrm{SiO}_{x} /$ $\mathrm{SiN}_{x}: \mathrm{H}$, resulting in the open-circuit voltage $\left(V_{\mathrm{oc}}\right)$ of the PERC solar cells even slightly lower than that of the AlBSF solar cells $[9,10]$. Rein's team studied the PERC solar cells using LFC (laser-fired contact) technology to form local electrical contact with the wafer on the rear side $[11,12]$. In fact, the industrialized PERC solar cells all use an $\mathrm{Al}_{2} \mathrm{O}_{3}$ layer or a thin $\mathrm{AlO}_{x}$ /thick $\mathrm{SiN}_{x}: \mathrm{H}$ cap layer to passivate the back surface and use laser ablation technology to open electrical contact windows on the back passivation layer. Finally, local back contact is formed on the rear side by screen printing the $\mathrm{Al}$ paste and sintering.

In view of the lack of research on the LID and regeneration of the industrialized boron-doped Cz-Si PERC solar cells, this paper is aimed at addressing this inadequacy. For regeneration treatment, there are two ways to inject carriers into a solar cell, i.e., light injection and electrical injection. Since electrical injection has some unique advantages over light injection, such as low equipment cost, energy saving, high injection level, and no light damage, electrical injection and heating were used in this paper to regenerate the industrialized boron-doped $\mathrm{Cz}-\mathrm{Si}$ PERC solar cells, and the effects of different regeneration process conditions (temperature, time, and injection current) on the antilight-induced degradation (anti-LID) performance of the
PERC solar cells were systematically investigated for the first time and the experimental results were reasonably explained by using the new three-state model proposed by Hallam et al. in 2016 [13]. The research results can be used as an important reference or even directly applied by the industry to further decrease or even completely remove the LID effect of the industrialized PERC solar cells, which is very important considering that the whole photovoltaic industry is transforming from producing conventional Al-BSF solar cells to higher-efficiency PERC solar cells, and the PERC solar cells are gradually becoming the mainstream products of the photovoltaic market.

\section{Experiment}

2.1. Sample Preparation. $156 \mathrm{~mm} \times 156 \mathrm{~mm}$ boron-doped $\mathrm{Cz}-\mathrm{Si}$ wafers with a round angle and a resistivity of about $1 \Omega \cdot \mathrm{cm}$ were fabricated into PERC solar cells by using the industrial standard process. The specific process includes the following: removing the saw damage layer and texturing using $\mathrm{KOH}$ solution, $\mathrm{POCl}_{3}$ diffusion at $850^{\circ} \mathrm{C}$ to form an emitter at about $85 \Omega / \square$, removing back PN junction using $\mathrm{HF} / \mathrm{HNO}_{3}$ solution, thermal oxidation at $750^{\circ} \mathrm{C}$ to form a $5 \mathrm{~nm}$ oxide layer, depositing a $20 \mathrm{~nm} \mathrm{AlO}_{x} / 140 \mathrm{~nm} \mathrm{SiN}$ passivation layer on the back side of the silicon wafers by PECVD at $400^{\circ} \mathrm{C}$, depositing about a $80 \mathrm{~nm} \mathrm{SiN}_{x}$ antireflection film on the front surface of the silicon wafers by PECVD at $450^{\circ} \mathrm{C}$, laser grooving on the back passivation layer to form electrical contact windows, screen printing the front and back electrodes, and sintering with temperature up to $800^{\circ} \mathrm{C}$. The initial efficiencies of the as-prepared PERC solar cells were in the range of $20.5 \%$ to $20.9 \%$.

2.2. Experimental Methods. First, the $I-V$ characteristics of as-prepared PERC solar cells were measured. Subsequently, the PERC solar cells were regenerated using different electrical injection and heating conditions on self-developed equipment, which consists of a WXD-2620 heating stage whose temperature can be regulated from room temperature to $400^{\circ} \mathrm{C}$, a JP8020D constant-current source with an output current range of 0-20 A, and a self-assembled probe holder for contacting the front electrode of a solar cell and a copper plate for contacting the back electrode of the solar cell. As the temperature displayed on the heating stage controller cannot accurately reflect the real temperature of a solar cell, it was determined by both a contact platinum RTD (resistance temperature detector) and a noncontact infrared thermometer. Then, the $I-V$ characteristics were measured again. After that, the regenerated solar cells were degraded by light soaking for $12 \mathrm{~h}$ with a light intensity of $1000 \mathrm{~W} / \mathrm{m}^{2}$ at $45^{\circ} \mathrm{C}$ in a YQ-GF-SC4 solar cell LID box. During the $12 \mathrm{~h}$ LID process, the PERC solar cells were taken out for $I-V$ measurement every $10 \mathrm{~min}$ in the first hour and every 1 hour thereafter. All the $I-V$ characteristic parameters of the solar cells were measured with a VS-6821M solar cell $I-V$ tester under standard test conditions (AM1.5 spectrum, $1000 \mathrm{~W} / \mathrm{m}^{2}, 25^{\circ} \mathrm{C}$ ). According to the claim of the manufacturer (IVT Corporation of Singapore) of the VS-6821M solar cell $I-V$ tester, the uncertainties of measurement results of short-circuit 
current $I_{\mathrm{sc}}$, open-circuit voltage $V_{\mathrm{oc}}$, fill factor FF, and efficiency $\eta$ in the confidence level of $95.4 \%$ are $4.99 \%, 0.51 \%$, $0.48 \%$, and $5.00 \%$, respectively. In order to compare the regeneration and anti-LID effects of the PERC solar cells regenerated by using different conditions, all the graphs in this paper use the relative values $\left(A_{t} / A_{\text {initial }}\right)$ of the $I-V$ characteristic parameters $\left(\eta, V_{\mathrm{oc}}, I_{\mathrm{sc}}\right.$, and FF) as the vertical axis.

\section{Results and Discussion}

3.1. Influences of Heating Temperature on the Regeneration Effect. Figure 1 shows the time dependence of the efficiency $\eta$ versus initial efficiency of the PERC solar cells before and after regeneration and during the subsequent $12 \mathrm{~h}$ LID process, which were regenerated by using $10 \mathrm{~A}$ injection current at different temperatures $\left(160,180,200,220,240\right.$, and $\left.260^{\circ} \mathrm{C}\right)$ for $30 \mathrm{~min}$. As shown in Figure 1, when the processing temperature is $260^{\circ} \mathrm{C}$, the $\eta$ of the PERC solar cell decreases slightly after the regeneration. In contrast, the $\eta$ of the PERC solar cell increases markedly after the regeneration at other processing temperatures. After the $12 \mathrm{~h} \mathrm{LID}$, the efficiencies of the PERC solar cells regenerated at lower temperatures $\left(160\right.$ and $180^{\circ} \mathrm{C}$ ) are higher than the initial values before regeneration, whereas the efficiencies of the PERC solar cells regenerated at higher temperatures $\left(200,220,240\right.$, and $\left.260^{\circ} \mathrm{C}\right)$ are lower than the initial values. Moreover, the decay rate of $\eta$ increases with increasing processing temperature, but the efficiencies of the regenerated PERC solar cells are all higher than that of the reference (untreated) sample.

Figure 2 shows a histogram describing the relative variation of $\eta$ of the PERC solar cells with processing temperature before and after regeneration with $10 \mathrm{~A}$ injection current for $30 \mathrm{~min}$, as well as before and after the subsequent $12 \mathrm{~h}$ LID. As shown in Figure 2, when the processing temperature is between 160 and $240^{\circ} \mathrm{C}$, the efficiencies of the regenerated PERC solar cells are all higher than the initial values and the increment of $\eta$ decreases with increasing temperature. When the temperature increases to $260^{\circ} \mathrm{C}$, the increment of $\eta$ becomes negative. After the $12 \mathrm{~h} \mathrm{LID}$, the decay rate of $\eta$ of the PERC solar cell regenerated at $180^{\circ} \mathrm{C}$ relative to the value before LID is lowest, which in fact corresponds to an

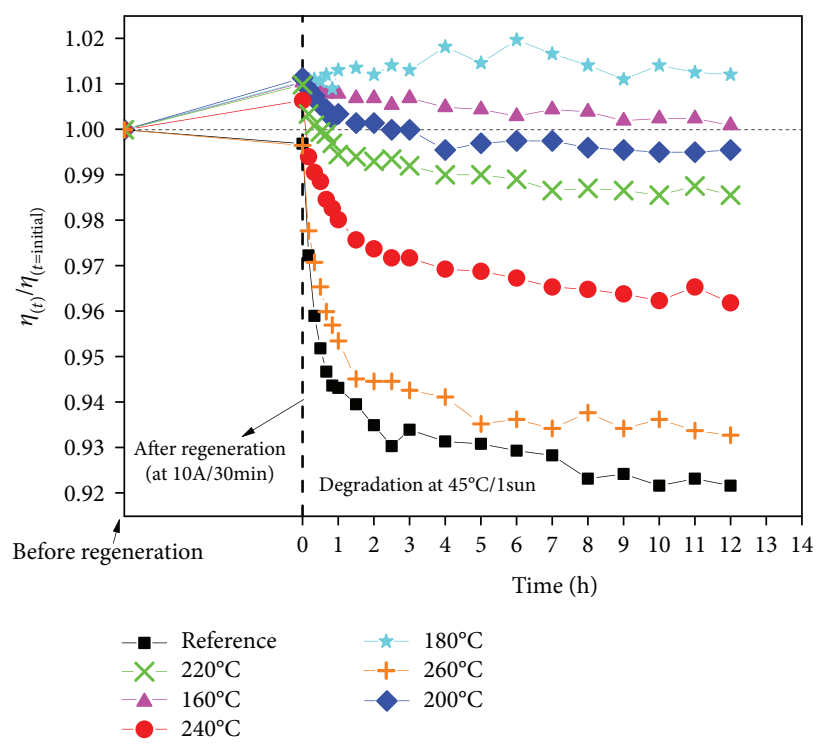

FIGURE 1: The variation of efficiency $\eta$ relative to the initial value of the PERC solar cells with time which were regenerated by using $10 \mathrm{~A}$ injection current at different temperatures $(160,180,200,220,240$, and $260^{\circ} \mathrm{C}$ ) for $30 \mathrm{~min}$ before and after regeneration and during the subsequent $12 \mathrm{~h}$ LID.

increment rate of $0.15 \%$. Furthermore, the decay rate increases with increasing processing temperature. Thus, the best anti-LID performance cannot be achieved by using too high or too low processing temperature. According to our experimental results, the optimal processing temperature is around $180^{\circ} \mathrm{C}$ for obtaining the best anti-LID performance.

The above results can be explained by the new three-state model of the B-O defects proposed by Hallam et al. in 2016 [13]. According to the new three-state model [13], there are three configurations of $\mathrm{B}-\mathrm{O}$ defects in boron-doped $\mathrm{Cz}-\mathrm{Si}$ wafers which are the annealed state (A) without recombination activity, degraded state $(\mathrm{B})$ with recombination activity, and passivated state $(\mathrm{C})$ without recombination activity. They can transform into each other by the following reaction formula:

\section{Annealed state (A) $\stackrel{\text { minority carrier injection }}{\underset{\text { annealing in dark }}{\leftarrow}}$ degraded state (B)}

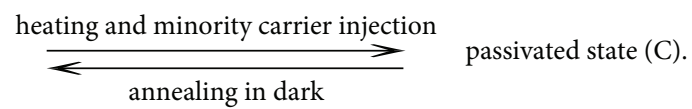

destabilization reaction from the passivated state $(C)$ to the degraded state (B) (the reaction rate is expressed as $K_{\mathrm{CB}}$ ). All the four reaction rates increase with increasing temperature, in which $K_{\mathrm{AB}}$ has a minimum increase rate and $K_{\mathrm{BA}}$ has a maximum increase rate, whereas both $K_{\mathrm{BC}}$ and $K_{\mathrm{CB}}$ have a moderate increase rate but $K_{\mathrm{BC}}$ is several orders of magnitude larger than $K_{\mathrm{CB}}$. The temperature-dependent curves of $K_{\mathrm{AB}}$ and $K_{\mathrm{BA}}$ intersect at about $180^{\circ} \mathrm{C}$, whereas between the three configurations; they are the degradation reaction from the annealed state $(A)$ to the degraded state (B) (the reaction rate is expressed as $K_{\mathrm{AB}}$ ), the annealing reaction from the degraded state $(B)$ to the annealed state (A) (the reaction rate is expressed as $K_{\mathrm{BA}}$ ), the passivation reaction from the degraded state $(B)$ to the passivated state (C) (the reaction rate is expressed as $K_{\mathrm{BC}}$ ), and the 


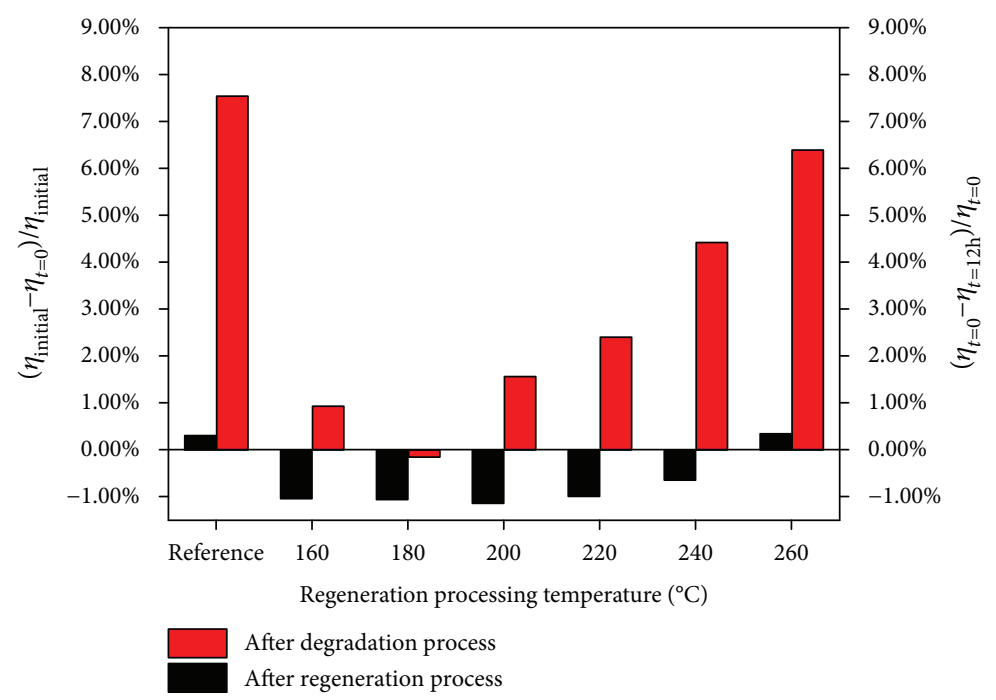

FIgURE 2: The histogram of the relative change of efficiencies of the PERC solar cells with processing temperature before and after regeneration with $10 \mathrm{~A}$ injection current for $30 \mathrm{~min}$, as well as before and after the subsequent $12 \mathrm{~h}$ LID.

the temperature-dependent curves of $K_{\mathrm{BC}}$ and $K_{\mathrm{BA}}$ intersect at around $320^{\circ} \mathrm{C}$. In the temperature range of $120-320^{\circ} \mathrm{C}$, the regeneration reaction rate $K_{\mathrm{BC}}$ is the largest among the four reaction rates (see reference [13] for details).

In the temperature range of $180-320^{\circ} \mathrm{C}, K_{\mathrm{BC}}>K_{\mathrm{BA}}>K_{\mathrm{AB}}$ and the difference between $K_{\mathrm{BC}}$ and $K_{\mathrm{BA}}$ decreases with the increase in temperature; therefore, when regenerated at this temperature range, a large part of the degraded states with recombination activity would transform into passivated states; meanwhile, a small part of the degraded states would transform into annealed states and a proportion of the annealed states to the passivated states would increase with rising temperature. Because the passivated states can only be transformed from the degraded states rather than from the annealing states, once annealing states are formed during the regeneration process, these annealing states would transform into the degraded states under the solar cell working conditions, resulting in the LID of the solar cells. Our evaluation criterion on the regeneration effect is that the ratio of the stable efficiency after $12 \mathrm{~h}$ LID to the initial efficiency of the PERC solar cell before regeneration should be maximized. That is to say, only the regeneration condition under which the highest content of the passivated states is obtained can be regarded as the best. Therefore, in order to make as much B-O defects as possible transform into the passivated states, the temperature interval of $120-180^{\circ} \mathrm{C}$ which corresponds to the condition of $K_{\mathrm{BC}}>K_{\mathrm{AB}}>K_{\mathrm{BA}}$ should be chosen in performing regeneration treatment. In the temperature range of $120-180^{\circ} \mathrm{C}$, the difference between $K_{\mathrm{BC}}$ and $K_{\mathrm{AB}}$ increases with increasing temperature, which means that higher temperatures can accelerate the passivation reaction. Therefore, under the condition of limited regeneration time, the regeneration at about $180^{\circ} \mathrm{C}$ can achieve the best regeneration effect.

Figures 3(a)-3(c) show the time dependence of $I_{\mathrm{sc}}, V_{\mathrm{oc}}$, and FF of the PERC solar cells versus the initial values before and after regeneration and during the subsequent $12 \mathrm{~h} \mathrm{LID,}$ which were regenerated by using $10 \mathrm{~A}$ injection current at different temperatures $\left(160,180,200,220,240\right.$, and $\left.260^{\circ} \mathrm{C}\right)$ for $30 \mathrm{~min}$, respectively. As shown in Figures 3(a) and 3(b), $I_{\mathrm{sc}}$ and $V_{\mathrm{oc}}$ basically have the same change tendency with $\eta$. Except for $260^{\circ} \mathrm{C}$, the $I_{\mathrm{sc}}$ and $V_{\mathrm{oc}}$ of the PERC solar cells regenerated at other temperatures are all higher than the initial values. After $12 \mathrm{~h} \mathrm{LID}$, the processing temperatures corresponding to the $I_{\mathrm{sc}}$ value higher than the initial value are $160^{\circ} \mathrm{C}$ and $180^{\circ} \mathrm{C}$, whereas the processing temperatures corresponding to the $V_{\mathrm{oc}}$ value higher than the initial value are 160,180 , and $200^{\circ} \mathrm{C}$. This result suggests that the larger decay of $I_{\mathrm{sc}}$ results in $\eta$ of the PERC solar cell regenerated at $200^{\circ} \mathrm{C}$ being lower than its initial value. In addition, when the processing temperature is higher than $180^{\circ} \mathrm{C}$, the decay rates of $I_{\mathrm{sc}}$ and $V_{\mathrm{oc}}$ relative to the initial values increase with the increasing temperature. It can be seen from Figure 3(c) that, after $12 \mathrm{~h}$ LID, the decay rates of FF of the regenerated PERC solar cells show an increasing tendency with the increase in the processing temperature. Specifically speaking, the decay rates of FF of the PERC solar cells regenerated at lower temperatures $\left(160^{\circ} \mathrm{C}, 180^{\circ} \mathrm{C}\right.$, and $\left.200^{\circ} \mathrm{C}\right)$ are lower than those of the reference sample, whereas the decay rates of FF of the PERC solar cells regenerated at higher temperatures $\left(220^{\circ} \mathrm{C}\right.$, $240^{\circ} \mathrm{C}$, and $260^{\circ} \mathrm{C}$ ) are higher than those of the reference sample. This result shows that too high temperature cannot improve the regeneration effect of the PERC solar cells but degrade their anti-LID performance.

3.2. Influences of Processing Time on the Regeneration Effect. Figure 4 shows the time dependence of efficiency $\eta$ versus the initial value of the PERC solar cells before and after regeneration and during the subsequent $12 \mathrm{~h}$ LID, which were regenerated by using $10 \mathrm{~A}$ injection current at $180^{\circ} \mathrm{C}$ for different times $(0,2,5,10,20$, and $30 \mathrm{~min})$. As shown in Figure 4, when the regeneration time is less than or equal to $10 \mathrm{~min}$, the $\eta$ of the regenerated PERC solar cells decreases markedly and the decay rates of the $\eta$ decrease with increasing processing time. Specifically speaking, the decay rates of $\eta$ corresponding to the processing times of 2, 5, and $10 \mathrm{~min}$ are 


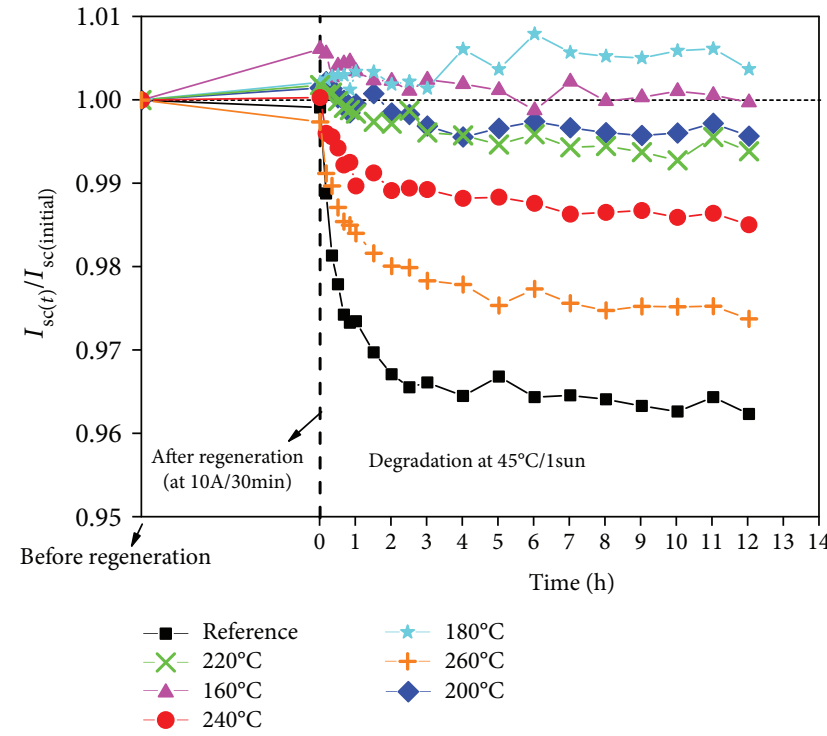

(a)

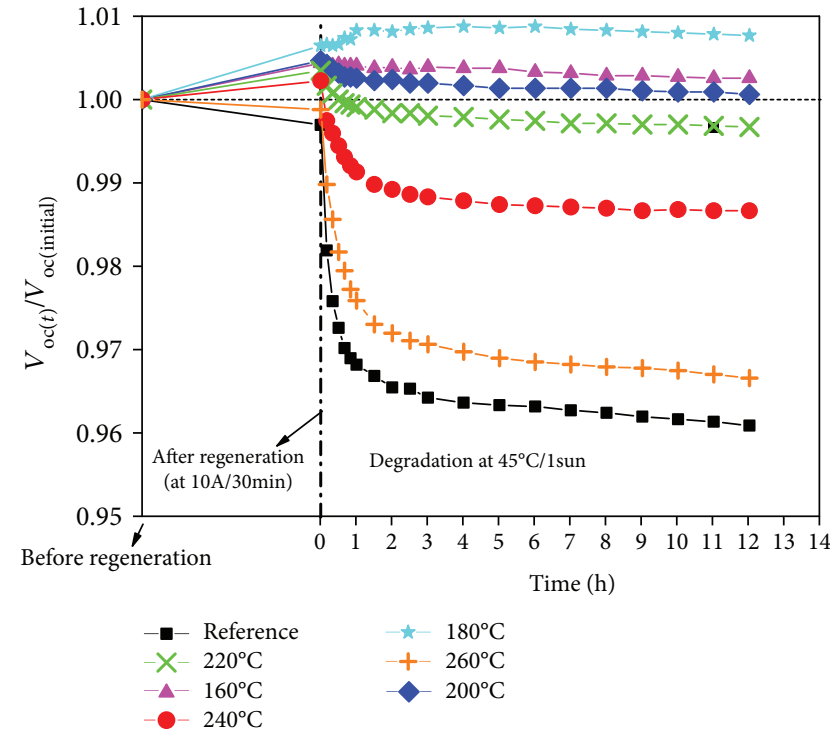

(b)

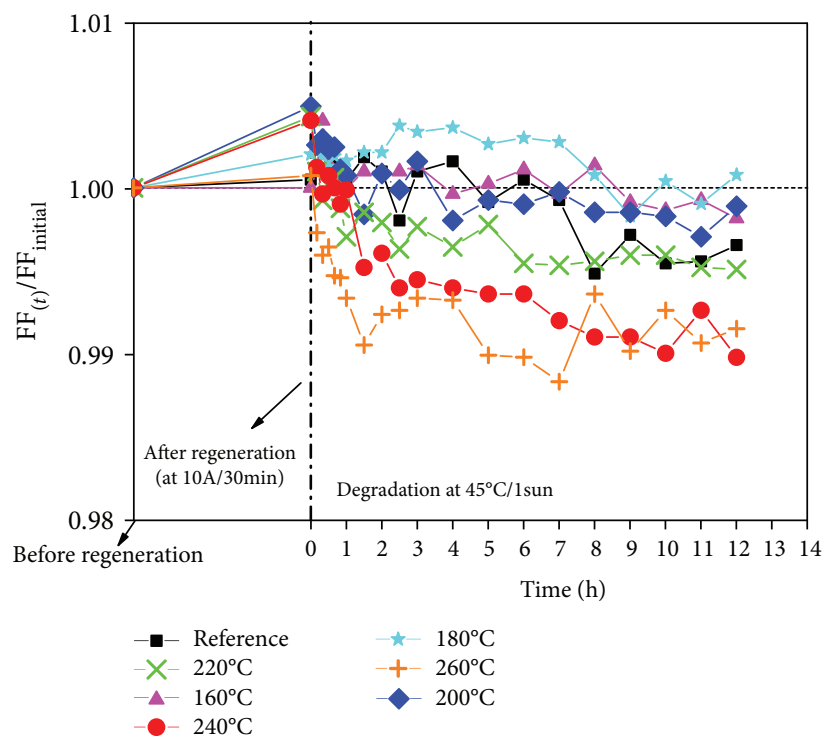

(c)

FIgURE 3: The time dependence of $I_{\mathrm{sc}}, V_{\mathrm{oc}}$, and FF of the PERC solar cells versus the initial values regenerated by using $10 \mathrm{~A}$ injection current at different temperatures $\left(160,180,200,220,240\right.$, and $\left.260^{\circ} \mathrm{C}\right)$ for $30 \mathrm{~min}$ before and after regeneration and during the subsequent $12 \mathrm{~h}$ LID: (a) $I_{\mathrm{sc}(t)} / I_{\mathrm{sc}(\text { initial })}$; (b) $V_{\mathrm{oc}(t)} / V_{\mathrm{oc}(\text { initial })}$; (c) $\mathrm{FF}_{(t)} / \mathrm{FF}_{(\text {initial })}$.

$4.87 \%, 4.07 \%$, and $2.77 \%$, respectively. For comparison, the PERC solar cells regenerated for 20 and $30 \mathrm{~min}$ and the reference sample have no obvious decay in efficiency. Moreover, the $\eta$ of the PERC solar cells regenerated for 20 and $30 \mathrm{~min}$ increases slightly. These results show that the $\eta$ of the PERC solar cells may decay when the regeneration time is shorter, whereas the $\eta$ of the PERC solar cells may recover and even exceed the initial values when the regeneration time is longer.

After $12 \mathrm{~h}$ LID, the reference sample shows significant degradation, with the decay rate of $\eta$ relative to the value before the LID up to $7.54 \%$. However, the decay rates of $\eta$ of the regenerated PERC solar cells decrease remarkably with increasing processing time; specifically speaking, the decay rates of $\eta$ corresponding to processing times of $2,5,10,20$, and $30 \mathrm{~min}$ are $1.27 \%, 0.84 \%,-0.05 \%,-0.08 \%$, and $-0.15 \%$, respectively. In particular, the PERC solar cells regenerated for 20 and $30 \mathrm{~min}$ even have a slight increase in efficiency with respect to the initial values before regeneration.

Figure 5 shows a histogram describing the relative variation of $\eta$ of the PERC solar cells with processing time before and after regeneration with $10 \mathrm{~A}$ injection current at $180^{\circ} \mathrm{C}$, as well as before and after the subsequent $12 \mathrm{~h}$ LID. As shown in Figure 5, the degradation of the reference sample is severer than those of regenerated PERC solar cells after $12 \mathrm{~h}$ LID. With the increase in regeneration time, both the decay rates 


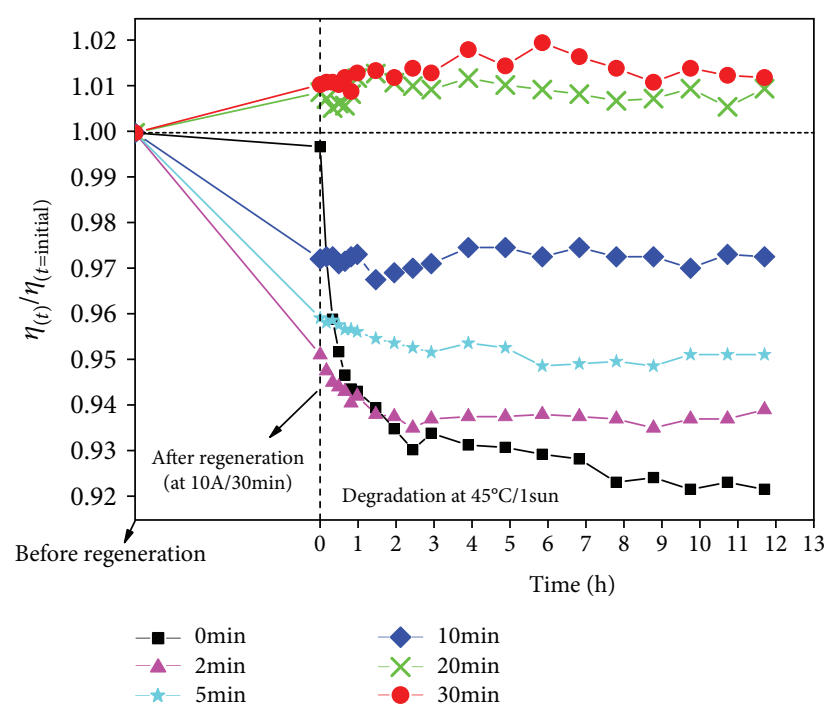

FIgURE 4: The time dependence of efficiency $\eta$ versus the initial value of the PERC solar cells before and after regeneration by using $10 \mathrm{~A}$ injection current at $180^{\circ} \mathrm{C}$ for different times $(0,2,5$, 10,20 , and $30 \mathrm{~min}$ ) and during the subsequent $12 \mathrm{~h}$ LID.

of $\eta$ after/before regeneration and those after/before $12 \mathrm{~h}$ LID gradually decrease and the decay rates of the latter are far below those of the former. In addition, when the regeneration time is longer than $10 \mathrm{~min}$, efficiencies of the PERC solar cells after $12 \mathrm{~h}$ LID are higher than those before the LID process. Thus, the anti-LID performances of PERC solar cells are enhanced with the increase in processing time.

According to the new three-state model proposed by Hallam et al. [13], BO defects have three composition forms, i.e., the annealed state without recombination activity, the degraded state with recombination activity, and the passivated state without recombination activity. The specific LID situations of boron-doped $\mathrm{Cz}$-Si PERC solar cells are determined by the concentrations of three defect states and the processing conditions. For the case given in this paper, before the regeneration, the $\mathrm{BO}$ defects in the as-prepared PERC solar cells mainly exist in the form of the annealed state, with a small amount of BO defects in the degraded state. Since the annealed state can only transform into the degraded state instead of the passivated state, the generation rate of the degraded state defects is much higher than that of the passivated state defects at the initial stage of the regeneration, which would result in a decrease in the bulk-carrier lifetime and efficiency of the solar cells. The amount of the degraded state defects increases with increasing processing time, so that the regeneration reaction would dominate at the middle-late stage of regeneration, and the concentration of the passivated state defects would increase with the increase in processing time. When the processing time is long enough, most of the annealed state and degraded state defects could convert into stable passivated state defects, which would lead to the recovery of the bulk-carrier lifetime and efficiency, making the regenerated PERC solar cells possess anti-LID performance.
Figures 6(a)-6(c) show the time dependence of $I_{\mathrm{sc}}, V_{\mathrm{oc}}$, and FF of the PERC solar cells versus the initial values before and after regeneration and during the subsequent $12 \mathrm{~h} \mathrm{LID,}$ which were regenerated by using $10 \mathrm{~A}$ injection current at $180^{\circ} \mathrm{C}$ for different times $(0,2,5,10,20$, and $30 \mathrm{~min}$, respectively). As shown in Figures 6(a) and 6(b), $I_{\text {sc }}$ and $V_{\text {oc }}$ basically have the same change tendency with $\eta$, and $I_{\mathrm{sc}}$ and $V_{\text {oc }}$ of the PERC solar cells regenerated for 20 and $30 \mathrm{~min}$ nearly have no distinct decay with respect to the initial value and almost remain stable in the subsequent $12 \mathrm{~h}$ LID. However, $I_{\mathrm{sc}}$ and $V_{\mathrm{oc}}$ of the PERC solar cells regenerated for less than or equal to $10 \mathrm{~min}$ have marked decay relative to the initial value, but their anti-LID performances are better than that of the reference sample during the subsequent $12 \mathrm{~h}$ LID and the anti-LID performances improve with the increase in regeneration time. In addition, during the $12 \mathrm{~h}$ LID, the relative values of $I_{\mathrm{sc}}$ of the PERC solar cells show a rising tendency with fluctuation, while those of $V_{\text {oc }}$ remain stable. The relative values of the FF before and after the regeneration basically have the same change tendency with those of $\eta, I_{\mathrm{sc}}$, and $V_{\mathrm{oc}}$. The decay rates of FF of the PERC solar cells regenerated for less than or equal to $10 \mathrm{~min}$ are higher than that of the reference sample, while the FF values of the PERC solar cell regenerated for 20 or $30 \mathrm{~min}$ are even slightly higher than the initial values before regeneration. During the $12 \mathrm{~h}$ LID, the decay rate of FF shows a different trend from those of $\eta, I_{\mathrm{sc}}$, and $V_{\mathrm{oc}}$. Specifically speaking, when the regeneration time is less than or equal to $10 \mathrm{~min}$, the decay rates of FF are larger than that of the reference sample, while the decay rates of FF of the PERC solar cells regenerated for 20 or $30 \mathrm{~min}$ are less than that of the reference sample. The above experimental results can be explained as follows: with the increase in the regeneration time, more recombination-active defects are passivated, which results in the increase in bulk-carrier lifetime and rise in $\eta, I_{\mathrm{sc}}$, and $V_{\text {oc }}$ of the PERC solar cells. Since FF is not only affected by the bulk-carrier lifetime but also affected by other factors such as series and parallel resistance, the FF would show a different change tendency from $\eta, I_{\mathrm{sc}}$, and $V_{\mathrm{oc}}$.

3.3. Influences of Injection Current on the Regeneration Effect. Figures 7(a)-7(d) show the time dependence of $\eta, I_{\mathrm{sc}}, V_{\mathrm{oc}}$, and FF of the PERC solar cells versus the initial values regenerated by using different injection currents $(6,8,10,12,14$, 16 , and $18 \mathrm{~A}$ ) at $180^{\circ} \mathrm{C}$ for $30 \mathrm{~min}$ before and after the regeneration and during the subsequent $12 \mathrm{~h}$ LID, respectively. As shown in Figure 7, $\eta, I_{\mathrm{sc}}, V_{\mathrm{oc}}$, and FF of the PERC solar cells regenerated by using different injection currents at $180^{\circ} \mathrm{C}$ for $30 \mathrm{~min}$ are all higher than the initial values before the regeneration. During the $12 \mathrm{~h}$ LID, $I_{\mathrm{sc}}$ shows a mild fluctuation, while $V_{\text {oc }}$ shows a slight decrease tendency and FF decreases with fluctuation; as a result, $\eta$ shows a slight decline tendency with fluctuation. After $12 \mathrm{~h} \mathrm{LID,} I_{\mathrm{sc}}$ and $V_{\mathrm{oc}}$ of the PERC solar cells regenerated with different injection currents are all higher than the initial values before the regeneration, while only the FF values of the PERC solar cells regenerated by using $10 \mathrm{~A}, 16 \mathrm{~A}$, and $18 \mathrm{~A}$ are higher than the initial values; consequently, efficiencies of the PERC solar cells regenerated by the current other than $12 \mathrm{~A}$ are higher than 


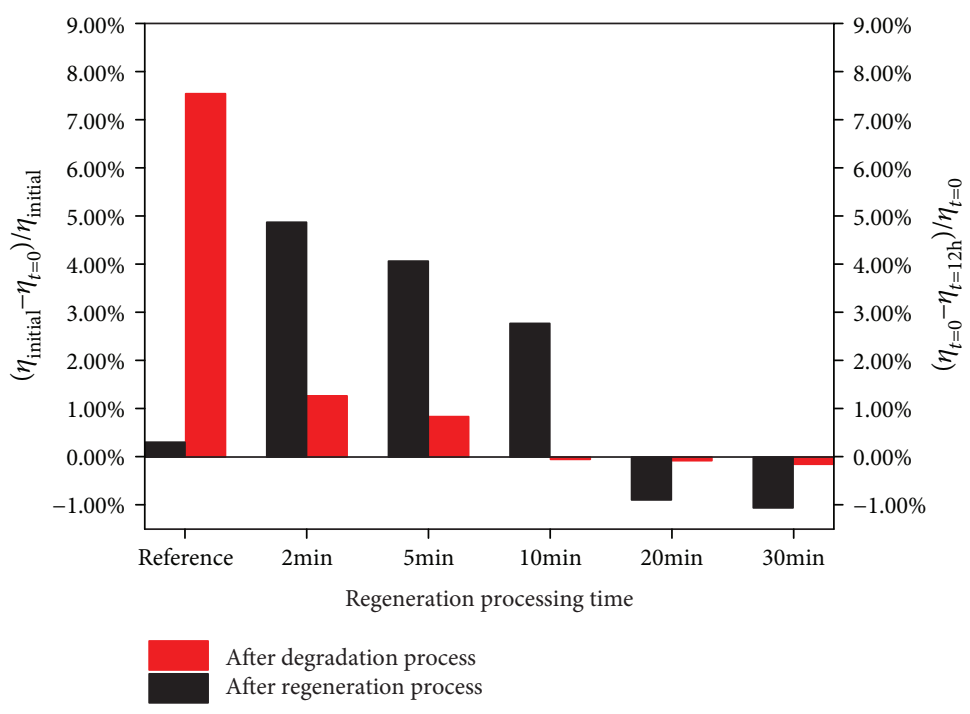

FIGURE 5: The processing time-dependent histogram of the relative change of $\eta$ of the PERC solar cells before and after regeneration with $10 \mathrm{~A}$ injection current at $180^{\circ} \mathrm{C}$, as well as before and after the subsequent $12 \mathrm{~h} \mathrm{LID}$.

the initial values. The above results show that under the condition of $180^{\circ} \mathrm{C}$ and $30 \mathrm{~min}$, the injection current of $6 \mathrm{~A}$ is big enough to obtain a good regeneration effect, and raising the injection current does not necessarily improve the regeneration effect. Given the processing temperature and time, the best regeneration effect seems to correspond to an optimum injection current. According to our experimental results, the optimal injection current corresponding to the conditions of $180^{\circ} \mathrm{C}$ and $30 \mathrm{~min}$ is around $10 \mathrm{~A}$. Of course, it still needs further investigation to achieve the best regeneration effect by decreasing the processing time meanwhile increasing the injection current.

In the studied parameter range, the optimum regeneration condition corresponds to the treatment with $10 \mathrm{~A}$ injection current for $30 \mathrm{~min}$ at $180^{\circ} \mathrm{C}$. Under such an optimum regeneration condition, the ratio of the efficiency during $12 \mathrm{~h}$ LID to the initial efficiency reaches the maximum value of 1.019 at $6 \mathrm{~h}$ light soaking and a stabilized value of 1.012 at $12 \mathrm{~h}$ light soaking (see Figure $7(\mathrm{a})$ ). It seems that the fluctuation of efficiency with time could be attributed to the nature of reversible reaction between the three configurations of B-O defects and a mixture of three states being generally reached. The reason why the efficiencies of suitably regenerated PERC solar cells after $12 \mathrm{~h}$ LID exceed the initial efficiency is that we did not perform annealing treatment $\left(200^{\circ} \mathrm{C}, 30 \mathrm{~min}\right)$ in the dark to make all the $\mathrm{B}-\mathrm{O}$ defects convert into annealing states before measuring the initial efficiency. The majority of degraded state defects contained in the as-prepared PERC solar cells transform into passivated states after suitable regeneration which results in the rising of efficiency.

It was reported that "a very fast regeneration process less than $10 \mathrm{~s}$ at $230^{\circ} \mathrm{C}$ and 2.7 -sun illumination can be realized." However, this conclusion was drawn from the research on the lifetime samples which were well gettering $\left(\mathrm{POCl}_{3}\right.$ gettering at $840^{\circ} \mathrm{C}$ ), well hydrogenated (PECVD-SiN ${ }_{x}: \mathrm{H}$ on both sides), suitably fired, and completely degraded $\left(200^{\circ} \mathrm{C}\right.$ annealing for $10 \mathrm{~min}$ in the dark) $[14,15]$. More importantly, the authors did not provide the direct proof of the stability of the optimally regenerated lifetime sample under solar cell working conditions $[14,15]$. Obviously, this fast regeneration condition is not in good agreement with ours. The reason is as follows: (1) PECVD-SiN $\mathrm{P}_{x} \mathrm{H}$ and electrode firing process conditions used for fabricating PERC solar cells in the industry are optimized to maximize the efficiencies of the PERC solar cells, which are different from the optimum fabrication condition of the lifetime sample. In addition, no $200^{\circ} \mathrm{C}$ annealing in the dark was performed on the as-prepared PERC solar cells before regeneration. (2) The judging criteria on the optimum regeneration condition are also different. Specifically speaking, the optimum light injection regeneration condition was determined by fully recovering the lifetime of completely degraded sample under the illumination and heating condition, whereas our judging standard is to maximize the ratio of the stable efficiency of a regenerated solar cell after $12 \mathrm{~h} \mathrm{LID}\left(45^{\circ} \mathrm{C}, 1\right.$-sun illumination) to the initial efficiency before regeneration, which means that only the regeneration condition under which the highest content of passivated states is obtained can be regarded as the optimum one. Moreover, the reason why the optimum regeneration can be achieved at $180^{\circ} \mathrm{C}$ has also been given a reasonable explanation according to the new three-state model proposed by Hallam et al. (see Section 3.1 for details). (3) Because the manufacturing process and architecture of a solar cell have complex and important influence on the regeneration and LID process, the conclusions drawn on the regeneration and LID of lifetime samples cannot be directly applied to those of the solar cells [16] and the conclusions given by this paper are only valid for the industrialized PERC solar cells.

Due to the scarcity of reports on light injection regeneration and anti-LID performance of industrial PERC solar cells, we cannot compare our research results with those by light injection regeneration. However, in our opinion, 


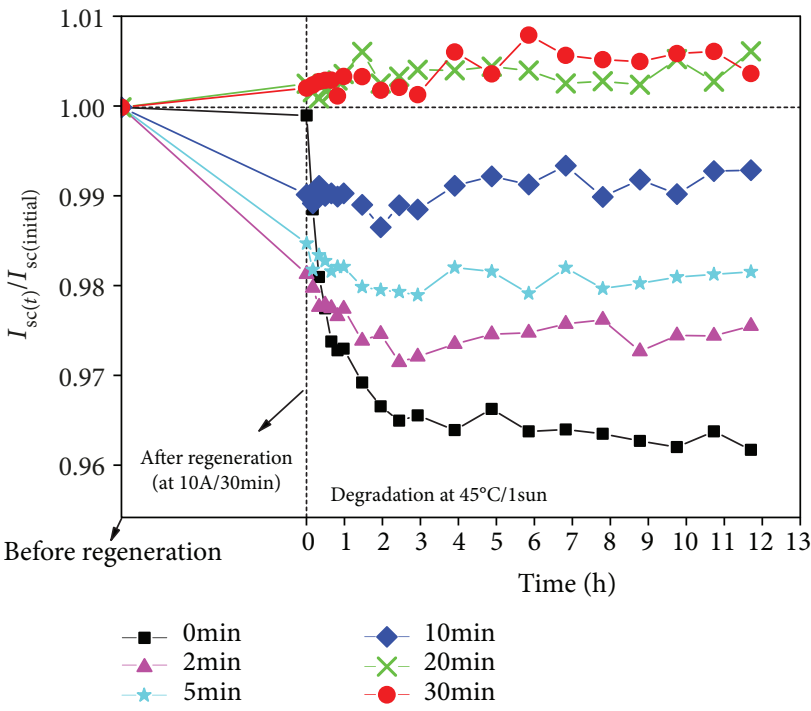

(a)

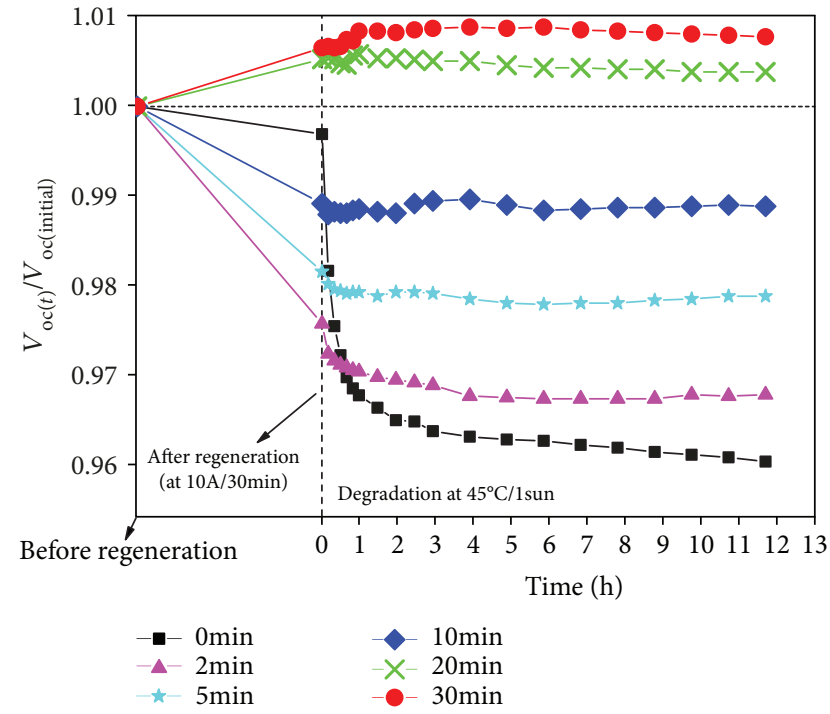

(b)

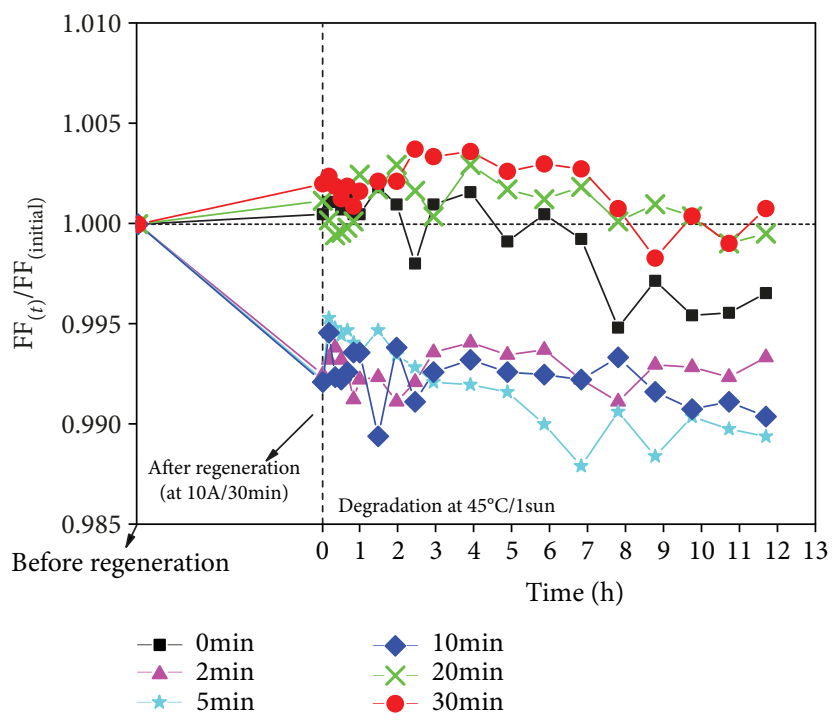

(c)

Figure 6: The time dependence of $I_{\mathrm{sc}}, V_{\mathrm{oc}}$, and $\mathrm{FF}$ of the PERC solar cells versus the initial values regenerated by using $10 \mathrm{~A}$ injection current at $180^{\circ} \mathrm{C}$ for different times $(0,2,5,10,20$, and $30 \mathrm{~min})$ before and after regeneration and during the subsequent $12 \mathrm{~h}$ LID: (a) $I_{\mathrm{sc}(t)} / I_{\mathrm{sc}(\text { initial })}$; (b) $V_{\mathrm{oc}(t)} / V_{\mathrm{oc}(\text { initial })}$; (c) $\mathrm{FF}_{(t)} / \mathrm{FF}_{(\text {initial })}$.

this work is worthy of being published for the following reasons: (1) electrical injection has some significant advantages over light injection, such as more simple equipment thus leading to lower equipment cost, higher energy utilization efficiency (without electricity-to-light and light-to-electricity conversion), and higher injection level without worry of light damage. (2) Since the electric injection regeneration apparatus can be made into a batch processing equipment [17], there is no problem to integrate a $30 \mathrm{~min}$ anti-LID batch processing procedure into a solar cell manufacturing process, because the manufacturing process also uses other time-consuming batch processing procedures such as the diffusion process and PECVD-SiN $\mathrm{S}_{x} \mathrm{H}$ process. (3) From the point of view of the mechanism, whether light injection or electric injection, they are just the methods to introduce nonequilibrium minority carriers (i.e., electrons) into boron-doped $\mathrm{Cz}-\mathrm{Si}$ wafers. The injected electrons can combine the nearby hydrogen ions $\left(\mathrm{H}^{+}\right)$to form hydrogen atoms, and hydrogen atoms can diffuse more quickly when heated and thus can effectively passivate the defects with recombination activity. It is thought that moderate temperature, higher injection level, and higher hydrogen concentration can give a better regeneration effect $[14,15]$. Unlike light injection, electric injection will not bring damages in a solar cell at high injection levels; thus, the electric injection should have a better regeneration effect than the light injection. (4) Different from the most of previous studies on LID and regeneration which were mainly characterized by lifetime or $V_{\mathrm{oc}}$, all the illuminated $I-V$ characteristic 


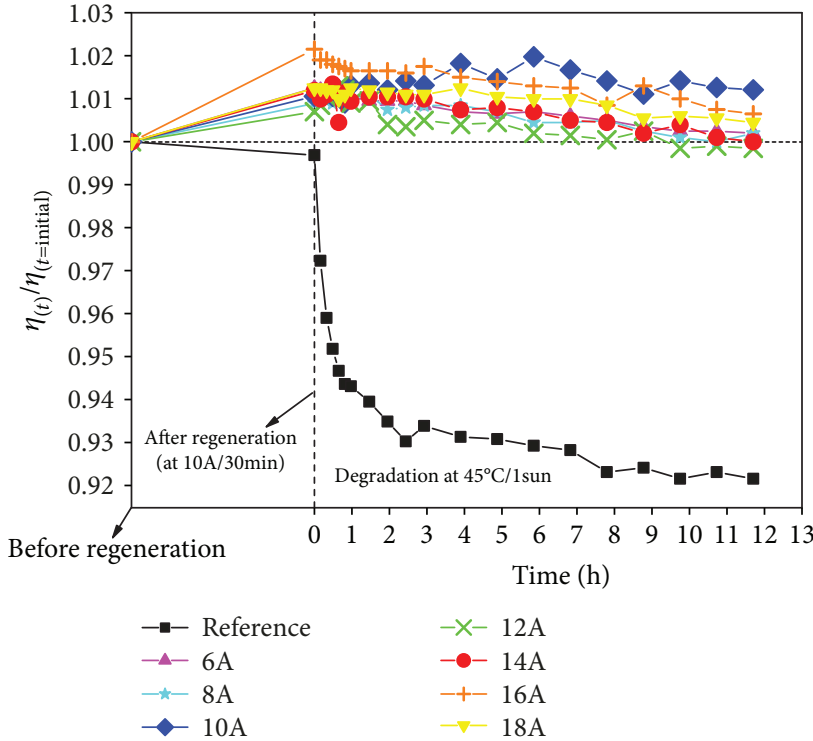

(a)

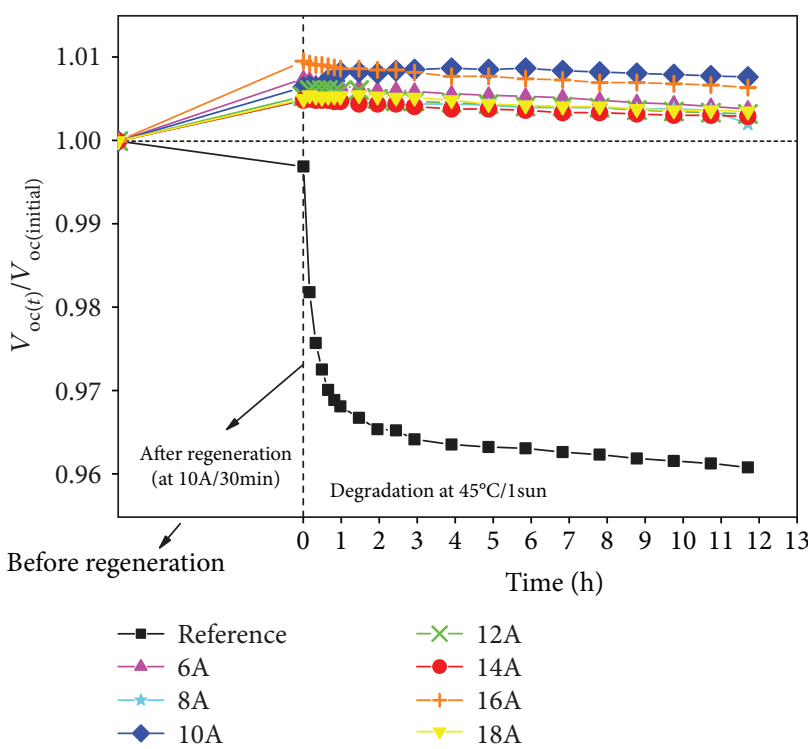

(c)

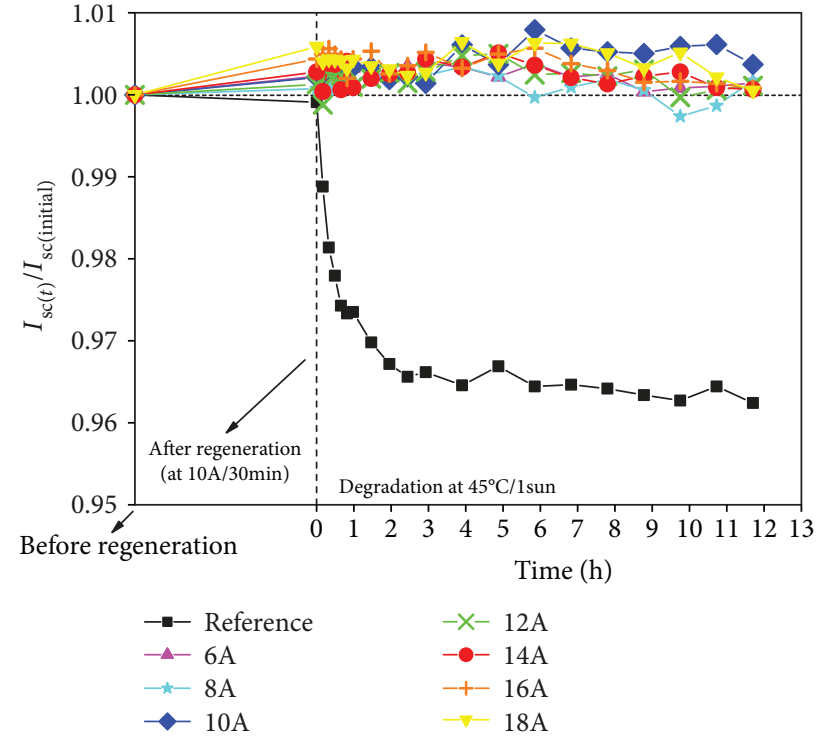

(b)

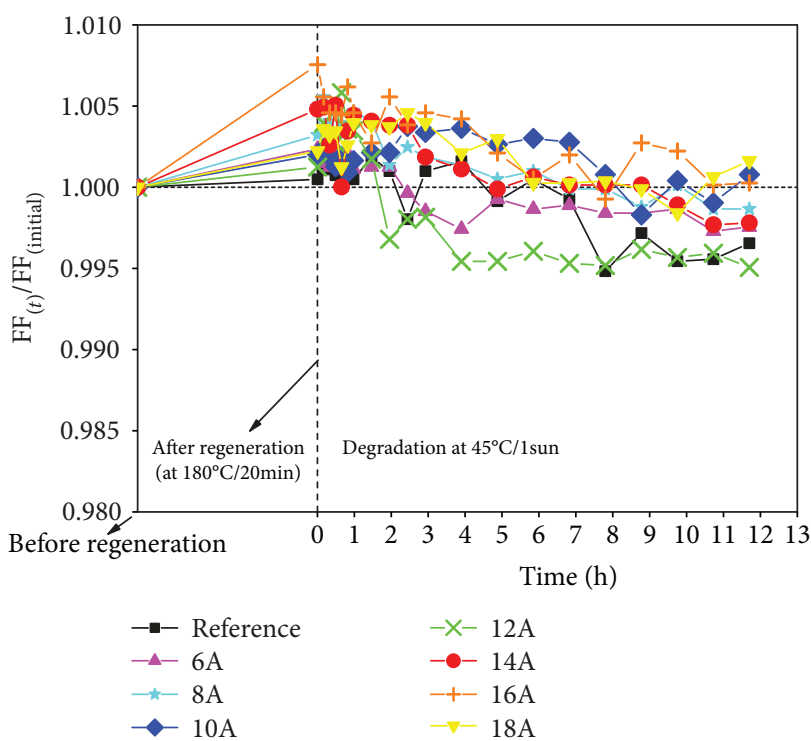

(d)

FIgURE 7: The time dependence of $I-V$ characteristic parameters of the PERC solar cells versus the initial values regenerated by using different injection currents $(6,8,10,12,14,16$, and $18 \mathrm{~A})$ at $180^{\circ} \mathrm{C}$ for $30 \mathrm{~min}$ before and after regeneration and during the subsequent $12 \mathrm{~h}$ LID: (a) $\eta_{(t)} / \eta_{\text {(initial) }} ;$ (b) $I_{\mathrm{sc}(t)} / I_{\mathrm{sc}(\text { initial })} ;(\mathrm{c}) V_{\mathrm{oc}(t)} / V_{\mathrm{oc}(\text { initial })} ;$ (d) $\mathrm{FF}_{(t)} / \mathrm{FF}_{(\text {initial })}$.

parameters $\left(\eta, V_{\mathrm{oc}}, I_{\mathrm{sc}}\right.$, and $\left.\mathrm{FF}\right)$ are used in this paper to characterize the regeneration and anti-LID performance of the industrialized PERC solar cells. In addition, the research results can be used as an important reference or directly used by the industry to further decrease or completely eliminate the LID problems of the industrialized PERC solar cells.

\section{Conclusion}

The PERC solar cells were fabricated by using the industrial standard process and treated by using different regeneration (electrical injection and heating) conditions, and the effects of the regeneration conditions (temperature, time, and injection current) on the anti-LID performance of as-prepared PERC solar cells were studied. The results show that the $I_{\mathrm{sc}}$, $V_{\text {oc }}$, and $\eta$ of the PERC solar cell regenerated at $180^{\circ} \mathrm{C}$ under the condition of $10 \mathrm{~A}$ injection current and $30 \mathrm{~min}$ processing time have the lowest degradation rate relative to the values before LID, which in fact corresponds to the maximum increment. When the processing time is less or equal to 10 min under the condition of $180^{\circ} \mathrm{C}$ and $10 \mathrm{~A}$ injection current, the $\eta, I_{\text {sc }}$, and $V_{\text {oc }}$ of the regenerated PERC solar cells with respect to the initial values before the regeneration decays markedly, but during the subsequent $12 \mathrm{~h}$ LID, their anti-LID performances are better than that of the reference 
sample and their anti-LID performances improve with the increasing processing time. When the processing time is 20 or $30 \mathrm{~min}$, the $\eta, I_{\mathrm{sc}}$, and $V_{\mathrm{oc}}$ of the regenerated PERC solar cells increase slightly relative to the initial values before the regeneration and basically remain stable during the subsequent $12 \mathrm{~h}$ LID. Under the condition of $180^{\circ} \mathrm{C}$ and $30 \mathrm{~min}$, $6 \mathrm{~A}$ injection current is enough to obtain a good regeneration effect, but the optimum injection current at such a condition is around $10 \mathrm{~A}$.

\section{Data Availability}

The data used to support the findings of this study are included within the paper. The raw data measured with a VS-6821M solar cell $I$ - $V$ tester are provided as supplementary materials.

\section{Conflicts of Interest}

The authors declare that there is no conflict of interests regarding the publication of this paper.

\section{Acknowledgments}

This work was supported by the National Natural Science Foundation of China (Grant no. 61774171) and the Special Scientific Research Program of Guangzhou (Grant no. 201607020032).

\section{Supplementary Materials}

The supplementary material is the raw data measured with a VS-6821M solar cell $I-V$ tester before and after regeneration treatment and during the subsequent $12 \mathrm{~h}$ LID process shown in Section 3.1, Section 3.2, and Section 3.3 of the manuscript. (Supplementary Materials)

\section{References}

[1] J. Lindroos and H. Savin, "Review of light-induced degradation in crystalline silicon solar cells," Solar Energy Materials and Solar Cells, vol. 147, pp. 115-126, 2016.

[2] Y. Wu, X. Yu, H. He, P. Chen, and D. Yang, "Suppression of boron-oxygen defects in Czochralski silicon by carbon codoping," Applied Physics Letters, vol. 106, article 102105, 2015.

[3] S. Martell, "Boosting PERC solar cell output," Advanced Materials \& Processes, vol. 175, pp. 29-30, 2017.

[4] T. Dullweber and J. Schmidt, "Industrial silicon solar cells applying the passivated emitter and rear cell (PERC) concept-a review," IEEE Journal of Photovoltaics, vol. 6, no. 5, pp. 1366-1381, 2016.

[5] T. Mchedlidze, A. Herguth, and J. Weber, "Monitoring of Sisolar cell degradation with electroluminescence," Solar Energy Materials and Solar Cells, vol. 155, pp. 38-42, 2016.

[6] A. Herguth, G. Schubert, M. Kaes, and G. Hahn, "A new approach to prevent the negative impact of the metastable defect in boron doped $\mathrm{Cz}$ silicon solar cells," in Proceedings of the 4th World Conference on Photovoltaic Energy Conversion (WCPEC-4), pp. 940-943, Waikoloa, Hawaii, USA, 2006.
[7] A. Herguth, G. Schubert, M. Kaes, and G. Hahn, "Avoiding boron-oxygen related degradation in highly boron doped $\mathrm{Cz}$ silicon," in Proceedings of the 21st European Photovoltaic Solar Energy Conference and Exhibition (EUPVSEC), pp. 530-537, Dresden, Germany, 2006.

[8] P. Basnyat, B. Sopori, S. Devayajanam et al., "Experimental study to separate surface and bulk contributions of light-induced degradation in crystalline silicon solar cells," Emerging Materials Research, vol. 4, no. 2, pp. 239-246, 2015.

[9] A. Herguth, R. Horbelt, S. Wilking, R. Job, and G. Hahn, “Comparison of BO regeneration dynamics in PERC and Al-BSF solar cells," Energy Procedia, vol. 77, pp. 75-82, 2015.

[10] F. Wolny, T. Weber, G. Fischer, A. Herguth, and S. Wilking, "Enhanced stable regeneration of high efficiency $\mathrm{Cz}$ PERC cells," Energy Procedia, vol. 77, pp. 546-550, 2015.

[11] F. Fertig, K. Krauß, and S. Rein, "Light-induced degradation of PECVD aluminium oxide passivated silicon solar cells," Physica Status Solidi (RRL)-Rapid Research Letters, vol. 9, no. 1, pp. 41-46, 2015.

[12] K. Krauss, F. Fertig, D. Menzel, and S. Rein, "Light-induced degradation of silicon solar cells with aluminiumoxide passivated rear side," Energy Procedia, vol. 77, pp. 599-606, 2015.

[13] B. Hallam, M. Abbott, N. Nampalli, P. Hamer, and S. Wenham, "Influence of the formation- and passivation rate of boron-oxygen defects for mitigating carrier-induced degradation in silicon within a hydrogen-based model," Journal of Applied Physics, vol. 119, no. 6, article 065701, 2016.

[14] S. Wilking, J. Engelhardt, S. Ebert, C. Beckh, A. Herguth, and G. Hahn, "High speed regeneration of BO-defects : improving long-term solar cell performance within seconds," in Proceedings of the 29th European Photovoltaic Solar Energy Conference and Exhibition (EUPVSEC), pp. 366-372, Amsterdam, Netherlands, 2014.

[15] S. Wilking, C. Beckh, S. Ebert, A. Herguth, and G. Hahn, "Influence of bound hydrogen states on BO-regeneration kinetics and consequences for high-speed regeneration processes," Solar Energy Materials \& Solar Cells, vol. 131, pp. 2-8, 2014.

[16] A. Herguth, S. Wilking, R. Horbelt et al., "Accelerating boronoxygen related regeneration : lessons learned from the BORNEO project," in Proceedings of the 31st European Photovoltaic Solar Energy Conference and Exhibition (EUPVSEC), pp. 804807, Hamburg, Germany, 2015.

[17] A. Herguth and G. Hahn, "Towards a high throughput solution for boron-oxygen related regeneration," in Proceedings of the 28th European Photovoltaic Solar Energy Conference and Exhibition (EUPVSEC), pp. 1507-1511, Paris, France, 2013. 

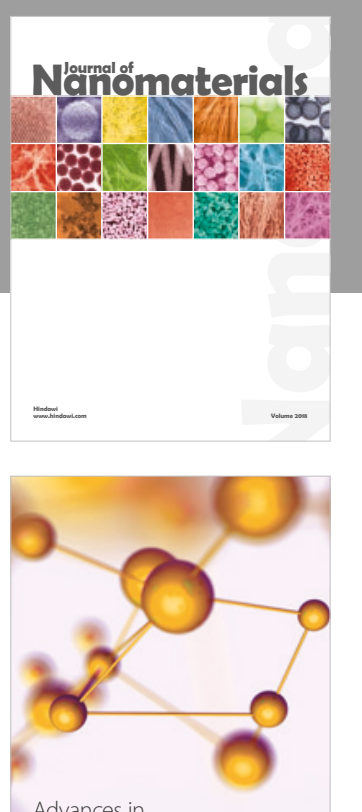

Physical Chemistry
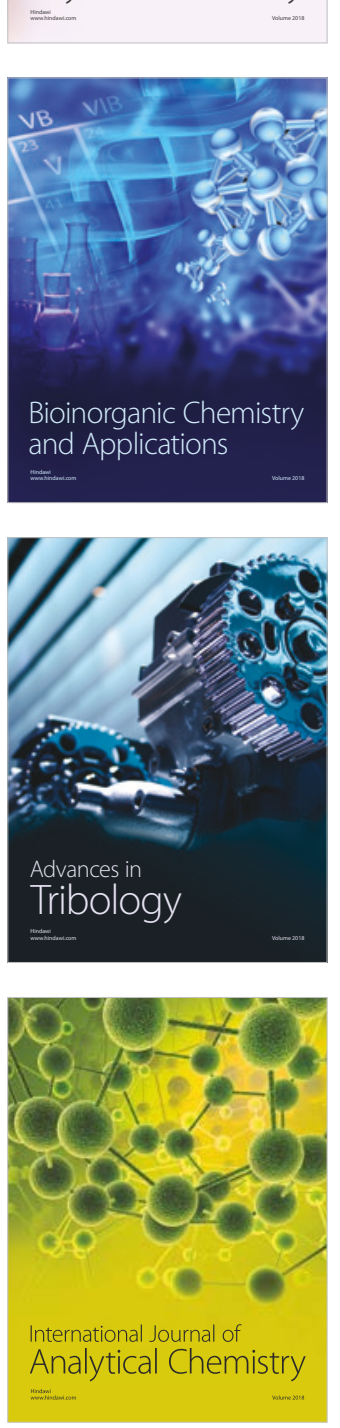

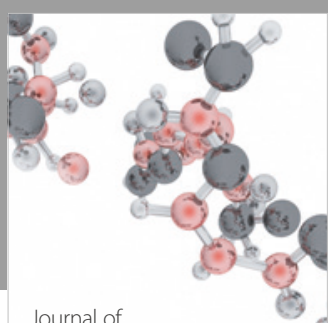

Analytical Methods

in Chemistry

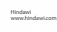

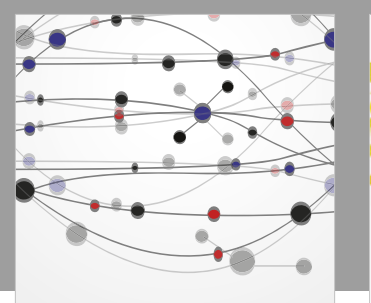

The Scientific World Journal

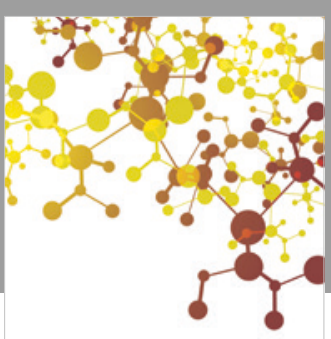

Journal of

Applied Chemistry
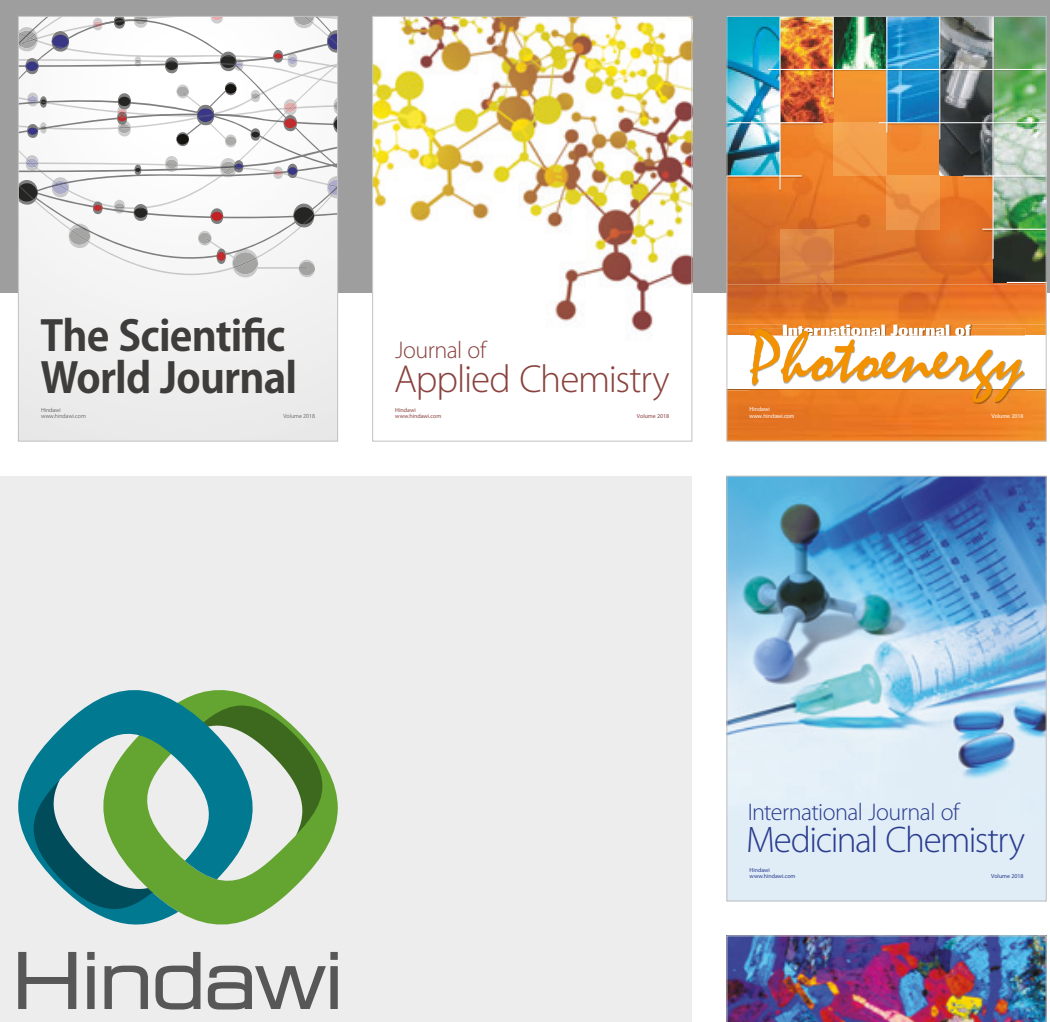

Submit your manuscripts at

www.hindawi.com
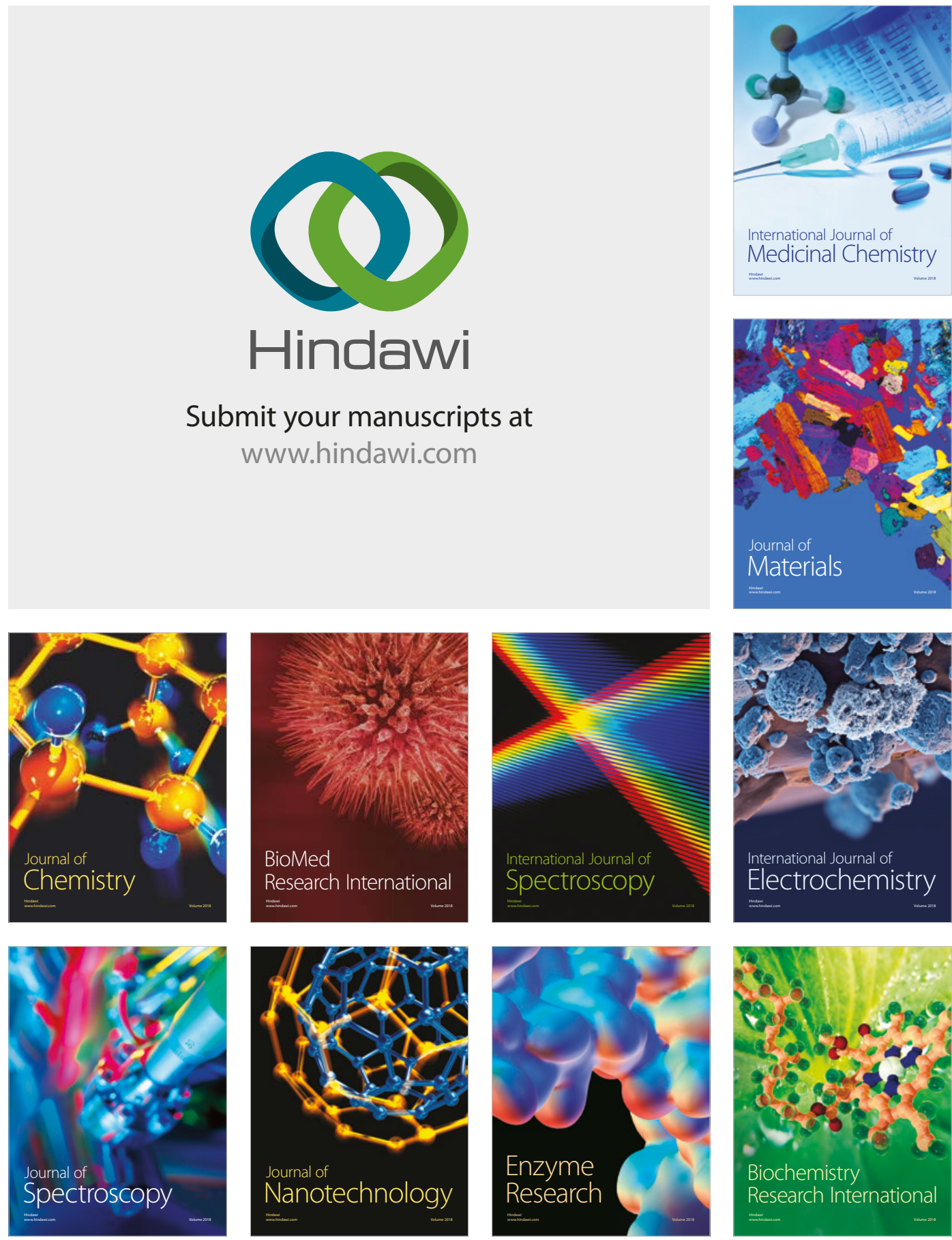
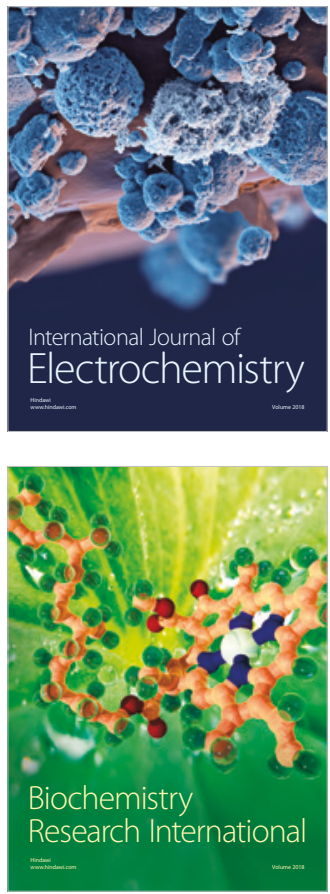